\title{
ИЗ ИСТОРИИ СЕМАНТИКИ СЛОВА «КОЛЫМА»
}

\section{FROM THE HISTORY OF SEMANTICS OF THE WORD «KOLYMA» ${ }^{2}$}

\section{A. Semyonov}

Summary: The purpose of our research is to clarify the lexical semantics of the word "Kolyma». Based on the analysis of lexicographic sources, contextual analysis, using both modern written sources and texts of business writing of the Old Russian time, we fix along with the meanings of this proper name indicated in the scientific literature («hydronymic», "resource», "camp», "administrative «) The functioning of a» narrow «spatial significance - 'the territory adjacent to the Kolyma River'. This region has been known since the 17th century. Over the next centuries, it was for a long time the main means of naming this territory, and in the 20th century. due to intensive study and significant economic development of the region, it was supplemented with options that are of broader significance. The novelty of the work lies not only in fixing the specified value, but also in the description of its origin, in the consideration of its regional specifics. «Narrow» territorial semantics originally arose in the phrase "Kolyma-river», and then developed in the hydronym of interest to us. The regional aspect in the use of the meanings under consideration is manifested in the fact that the «narrow» semantics of the toponym «Kolyma» is more characteristic of Yakutia, «wide» - for the Magadan region (today the regionim «Kolyma» and «Magadan region» function as synonyms).

Keywords: business writing, history of the Russian language, Russian old-time dialects, regional linguistics, regionalism, toponym, hydronym, regionym, Kolyma, North-East of Russia.

\author{
Семенов Алексей Иванович \\ к.филол.н., дочент, ФГБОУВО «Северо-Восточный \\ государственный университет», г. Магадан \\ aisemenoff@mail.ru
}

Аннотация: Целью нашего исследования является уточнение лексической семантики слова «Колыма». Опираясь на анализ лексикографических источников, контекстуальный анализ, используя как современные письменные источники, так и тексты деловой письменности старорусского времени, мы фиксируем наряду с указанными в научной литературе значениям этого имени собственного («гидронимное», «ресурсное», «лагерное», «админи(тративное») функционирование «узкого» пространственного значения 'территория, прилегающая к реке Колыме'. Этот регионим известен с XVII в. На протяжении последующих столетий он долгое время был основным средством назвать данную территорию, а в XX в. в связи с интенсивным изучением и значительным экономическим развитием региона был дополнен вариантами, которые имеют более широкие по значения. Новизна работы заключается не только в фиксации указанного значения, но и в описании его происхождения, в рассмотрении его региональной специфики. «Узкая» территориальная семантика первоначально возникла у словосочетания «Колыма-река», а затем развилась у интересующего нас гидронима. Региональный аспект в употреблении рассматриваемых значений проявляется в том, что «узкая» семантика топонима «Колыма» более характерна для Якутии, «широкая» — для Магаданской области (сегодня регионимы «Колыма» и «Магаданская область» функционируют как синонимы).

Ключевые слова: деловая письменность, история русского языка, русские старожильческие говоры, региональная лингвистика, регионализм, топоним, гидроним, регионим, Колыма, Северо-Восток России.

Деловые документы дают прежде всего ценный лексический материал, обращение к ним может не только обогатить наши представления о лексическом фонде диалектов, но и дополнить сведения о функционировании отдельных слов. Целью нашей работы является уточнить лексическую семантику топонима «Колыма». В исследовании мы использовали анализ лексикографических источников, контекстуальный анализ, привлекали как современные письменные источники, так и тексты деловой письменности старорусского времени, периода знакомства русских первопроходцев с северо-восточной территорией.

Имя собственное «Колыма» уже становилось предности см., например, в статье О.Е. Шепилевой [19, с. 151]).

Исследование выполнено при финансовой поддержке РФФИ в рамках научного проекта 20-012-00266 «Региональные варианты русского языка на Крайнем Северо-Востоке России».

2 The study was carried out with the financial support of the Russian Foundation for Basic Research within the framework of the scientific project 20-012-00266 "Regional variants of the Russian language in the Far North-East of Russia." 
метом лингвистического исследования. Так, в статье Е.М. Гоголевой «Лексемы «материк» и «Колыма» в общенациональном словаре и в региональной традиции» и в «Топонимическом словаре Северо-Востока СССР» В.В. Леонтьева и К.А. Новиковой, кроме гидронимного, выделяются одно или несколько территориальных значений [7; 12].

Что касается происхождения данного слова, то оно не имеет надежной этимологии. В.В. Леонтьев и К.А. Новикова существующие в литературе этимологические толкования (например, от якутского слова кулу 'река', от юкагирского кулема 'ловушка для медведя', от русского колым 'выкуп за жену'), характеризуют как «маловероятные предположения», по их мнению, «лишь в одном можно быть уверенным, что русские землепроходцы услышали название реки от юкагиров или якутов и адаптировали его в соответствии с фонетическими нормами русского языка» [12, с. 198]. В.В. Леонтьев и К.А. Новикова приводят примеры употребления фонетически близких с географическими наименованиями, которые представляют различные языки народов Северо-Востока, отмечают связь между данными гидронимами и характером географических объектов, которые названы этими именами, и высказывают предположение: «Возможно, что основы -куул-, -коол-, -кюел, -кёл, -кулу, относящиеся к гидронимам, имеют какую-то общую древнюю историческую связь и простираются от окраин Северо-Востока до Средней Азии (ср. озеро Иссык-Куль) и Горного Алтая» $[12$, c. 198].

Что касается семантики, то авторы «Топонимического словаря Северо-Востока СССР» обращают внимание на то, что уже с начала 1930-х гг. «под названием «Колыма» стали понимать и обширную часть Крайнего Северо-Востока» [12, с. 199]. Подтверждением данного утверждения являются, например, наблюдения И.Е. Гехтмана, который в своих пропагандистских очерках «Золотая Колыма», опубликованных в 1937 г., говорит о берегах охотоморской бухты Нагаева (сейчас это отчасти территория г. Магадана) как о «берегах Колымы». Для И.Е. Гехтмана Колыма - колоссальное по своим размерам пространство: «Колымский край - нынешний район деятельности Дальстроя - с юга омывается Охотским морем. Северная граница края проходит у полярного круга, западная - граничит со сто сорок пятым градусом восточной долготы, восточная - лежит на сто шестидесятом градусе. Это полмиллиона квадратных километров - территория, превышающая Германию.» (кстати сказать, частью этого огромного пространства является и Гижига, куда направляется со свой семьей офицер-пограничник, которого автор очерков встретил на корабле, плывущем к «берегам Колымы») [6].

Е.М. Гоголева выделила следующие семантические разновидности онима «Колыма»: во-первых, это гидро- ним:'река на северо-востоке Российской Федерации'; вовторых, это регионим, который представлен несколькими вариантами, у которых обнаруживаются следующие значения: 1) 'территория на северо-востоке Российской Федерации, богатая природными ресурсами (золото, серебро и др.) и имеющая суровый климат'; 2) 'территория на северо-востоке Российской Федерации, где во времена сталинских репрессий находились многочисленные лагеря для заключенных' (кроме того, обнаруживается и гораздо более широкое понимание онима: 'место заключения для осужденных (в прошлом и настоящем)'; 3) 'территория на северо-востоке Российской Федерации, совпадающая с современными границами Магаданской области' (до отделения Чукотки толкование было иным: 'Колыма и Чукотка - территории на северо-востоке Российской Федерации, составляющие Магаданскую область'). Каждое из перечисленных значений (условно называем их как «ресурсное», «лагерное» и «административное» значения) иллюстрируется Е.М. Гоголевой разнообразными примерами употребления; кроме того, демонстрируются соответствующие словообразовательные связи интересующего нас онима (колымчане, колымский и т.д.) [7].

На базе перечисленных могут формироваться новые значения. Так, например, к многочисленным примерам, приведенным Е.М. Гоголевой можно добавить слово «колыма» со значением 'заключенный имеющий длительный срок заключения' (или «Колыма», если речь идет о прозвище такого человека) [14, с. 272]. Данное значение явно сформировалось на основе «лагерной» семантики топонима «Колыма».

Также можно обратить внимание на употребление лексемы «колыма» в значении 'жилище'. Примеры берем из «Трудов Якутской научной рыбохозяйственной станции». Опубликованные в этом сборнике материалы представляют собой ценный источник для изучения не только ихтиологической, но и лингвистической проблематики. Данные материалы для исследования региональной, диалектной лексики Северо-Востока еще не привлекались. Так, С.В. Аверинцев в одной из своих статей, которые были опубликованы во 2-м выпуске этого сборника (1932 г.) данное слово упоминает дважды: «На береговом мыске стоит полуразвалившаяся хижина, «колыма»;; «Немного дальше стоят три колымы и слышен оглушительный лай» $[1$, с. 27, 37] (отметим, что при первом упоминании автор заключает интересующее нас слово в кавычки).

Нашей целью не является рассмотрение этимологии слова «колыма» в значении 'жилище', обратим внимание лишь на возможную связь с лексемой «калыман» со значением 'летнее жилище якута из дерна', происхождение которой А.Е. Аникин объясняет из якутского языка («kalyman», «kuluma» 'жилище (временное) зимнее, об- 
ложенное дерном' (для сравнения исследователь приводит и эвенкийское слово «голомо» 'чум из расколотых бревен, покрытый лиственничной корой и засыпаемый на зиму землей или снегом') [2, с. 243]. С одной стороны, слово «колыма» со значением'жилище' (возможно, то же, что «калыман») может быть заимствованием из якутского языка или даже непосредственно из эвенкийского, влияние топонима «Колыма» здесь заключается в аналогическом воздействии при переоформлении («kalyman» / «kuluma» $\rightarrow$ «колыма»). С другой стороны, лексема «колыма» может быть результатом деонимизации (апеллятивации) топонима «Колыма». Однако независимо от того, является ли данное наименование жилища результатом переоформления или деонимизации, возникает вопрос: с каким значением лексемы «Колыма» оно связано? «Территориальность» как периферийная сема обсуждаемого наименования жилища отдаляет его от гидронима, а с прочими значениями топонима (на хронологическом основании) это слово еще не связано.

Нам представляется необходимым к перечисленным Е.М. Гоголевой значениям добавить еще одно. Оно появилось задолго до открытия колымских полезных ископаемых, организации сталинских лагерей и возникновения Магаданской области: 'территория, прилегающая (примыкающая) к реке Колыме'. Это значение мы условно называем «узким», по сравнению с ним прочие пространственные значения (особенно «административное») выглядят «широкими».

По нашим наблюдениям, лексема «Колыма» с указанным «узким» значением сегодня активно функционирует, оно актуально для многих жителей населенных пунктов, расположенных непосредственно на берегах Колымы, в особенности если речь идет о жителях Якутии, где Колыма как пространство - это именно прибрежная территория (см. примеры в публикациях Б. Войцеховского, А. Горячева, Т. Никовой $[4 ; 8 ; 18])$. Разная актуальность значений для жителей Якутии и Магаданской области свидетельствует о региональных отличиях в употреблении этого слова: «узкое» - в Якутии, «широкое» (например, «административное») - в Магаданской области (за пределами Северо-Востока России, вероятно, наиболее востребованным является не столько «административное», сколько «лагерное» значение интересующего нас топонима). Можно предположить, что акцент на «широких» значениях в упомянутых выше словаре В.В. Леонтьева и К.А. Новиковой и статье Е.М. Гоголевой объясняется тем, что их авторы тесно связаны именно с Магаданской областью.

На базе гидронима «узкое» значение появилось первым из пространственных значений, и появилось оно, вероятно, очень рано.

В опубликованных документах середины XVII в. мож- но найти примеры: 1) Того ж дни отпущены ис таможни вниз по Лене реке и морем на Яну и на Индигирскую реку, и на Ковыму и в-ыные сторонные реки и на соболиной промысел и для торгу москвитина гостиной сотни Василья Федотова Гусельникова брата ево Афонасья Федотова («Из книги таможенной сбора отъезжих пошлин...»; запись 27 июня 1646 г., № 51; здесь и далее приводимая нумерация - это обозначение документа в цитируемом источнике); 2) Июля в 2 день отпущены из Якутцково острогу ис таможни вниз по Лене реке и на Индигирку, и на Ковыму и в-ыные стороные реки для торгу и соболиного промыслу гостя Василья, записи приказщика ево Семена Тимофеева Нерадовского, приказщик ево Ивашко Ондреев Широкой Черевковеи («Из книги таможенной <...> за 157 г.», 2 июля 1649 г., № 60) [15].

Данное значение наблюдается в источниках XVIIIXX вв.: <..> о успехах или непредусмотренных неудобностях и препядствиях пути вашего к Охотску и оттуда чрез Гижигинскна Ковыму... («Из наставления Адмиралтейств-коллегии И.И. Биллингсу», 1785 г., № 67) [16, с. 210]; <...> оставшиеся в живых пять человек пошли отсюда пешком на Колыму. [5, с. 342]; <...> Чукча рассказал, что он крещен на Колыме<...> ; <...> в Гижиге и на Колыме приготовляются нарочно наряды на российскочукотскую стать... (из наблюдений Ф. П. Литке, первая половина XIXв.) [13, с. 890, 897]; <...> как коряки, так и тунгусы вовсе не стесняются Гижигинского округа, но часто заходят в пределы Камчатки и Колымы (наблюдения Охотского окружного врача Богородского, 1853 г.) $[3$, с. 86]; <...> Уже теперь сообщают из Колымска, что с Колымы устанавливаются такие, например, чены... (Из доклада начальника Гижигинской экспедиции Н.М. Березкина о путях сообщения Колымского края и об изысканиях пути Среднеколымск - Гижига, 1912 г.) [9].

Изучение письменных документов по истории освоения Северо-Востока России показывает, что данное значение у слова «Колыма» появляется на основе словосочетания «Колыма-река», которое также очень рано (по аналогии с другими подобными сочетаниями слов) получило указанное территориальное значение. Приведем несколько примеров [15; 16]: 1) А Ковыма де река собольна, и которые сторонние реки пали в Ковыму реку, и те де реки собольны («Расспросные речи ленского служилого человека Лавра Григорьева и сына боярского Ивана Ерастова...», 29 сентября 1644 г., № 31); 2) ....nосылаю яз из Якутцкого острогу вниз по Лене из Енисейской проезжей грамоте на Индигирку и на Ковыму реку, и в-ыныя сторонныя реки приказщыков своих Матюшку Лукоянова да Бориска Васильева («Роспись хлебного запаса и промышленных товаров...», не позднее 4 июля1648 г., № 57); 3) И по се число на той Ковыме реке збираетца твой, государев, ясак немалой по вся годы безпереводно («Челобитная казачьего десятника Михаила Стадухина...», 1659/60 г., № 37); 4) Только де государь укажет по- 
слать с усть Муки реки на новые на Алазей и на Ковыму реки своих государевых служилых людей человек 30 в куяках да охочих промышленных людей с 30 же... («Расспросные речи служилых людей...», 1646 г., № 33); 5) Государю, царю и великому князю Алексею Михайловичю всеа Русии, воеводам Василью Никитичю, Кирилу Осиповичю, Петру Григорьевичу новоприисканой Ковымы реки таможенной человальник Петрушка Новоселов с товарищи, с торговыми и с промышлеными людьми челом бьют. («Отписка таможенного целовальника Петра Новоселова...», не ранее 9 сентября 1647 г. - не позднее 31 августа 1648 г., № 80); 6) ... с Ковымы реки послан я, Семейка, на новую реку на Онандырь для прииску новых неясачных людей. («Отписка казака Семена Дежнева якутскому воеводе И.П. Акинфову», не ранее 1 сентября 1654 г. - не позднее 5 апреля 1655 г.).

Итак, в документах XVIIв. гидроним (сначала, видимо, как «Ковыма», а затем все чаще - «Колыма») в сочетании с существительным «река» является также, вероятно, первоначальным средством выразить значение 'территория, прилегающая к реке Колыме'.

Использование в России рек в качестве транспортных артерий - важнейшее средство освоения новых земель в XVII в. (и в более поздние периоды), поэтому реки становятся необходимыми ориентирами на «новоприисканных» территориях (на местности, на географической карте), отсюда еще одно пространственное значение, связанное в том числе с рекой Колымой, 'географический ориентир'. Многочисленные образцы употребления наименований рек в качестве ориентиров, представленных в соответствующей синтаксической конструкции (типа От Илги реки до Тутуры реки 2 дни ходу), содержатся, например, в «Чертежной росписи притоков р. Лены в ее верхнем течении, пашенных мест, расстояний между устьями рек, со сведениями о местном населении» (№ 23) [15].

Несколько интересующих нас значений ('река Колыма,' 'территория, прилегающая к реке Колыме' и 'географический ориентир') в одном документе могут использоваться одновременно. В качестве примера возьмем «Сказку» знаменитого землепроходца Михаила Стадухина, которая датирована 26 апреля 1647 г. (№ 76) [15; 16, с. 73-74]. Интересующее нас имя собственное встречается в следующих случаях:

1. 155-го апреля в 26 день в Якуцком остроге в съезжей избе воеводам Василью Никитичю Пушкину да Кирилу Осиповичю Супоневу, да дияку Петру Стеншину служилой человек, которой в прошлом во 154-м году ноября в 23-м числе в Якуцкой острог до приезду воевод Василья Никитича Пушкина с товарищы с Колымы реки з государевым с ясачным збором пришол, Михалко Стадухин в роспросе сказал<...>.
2. На Колыме де реке был он для государева ясачного збору 3 годы.

3. А Колыма де река велика есть, с Лену реку <...> .

4. А по той де Колыме реке живут иноземцы колымские мужики свой род оленные и пешие сидячие многие люди и язык у них свой.

5. Да на той ж де Калыме в сторонней реке, прозвищем на Чюхче, а пала де та река Чюхча в море своим ж устьем с приезду по сей стороны Колымы реки.

6. <...> идучи х той Колыме реке судами <...> .

7. <...> идучи из Лены от Святого Носу, а к Яне де реке и от Яны к Собачье, а Индигирка тож, и от Индигирких Колыме реке идучи <...>.

8. И те де чюхчи по сю сторону Колымы от своего жилья с той речки зимою чюхчи переезжают на оленех на тот остров одним днем.

9. <...> а доброй де самой черной соболь все по Колыме.

10. А от Колымы де до реки ж, что выше той Колымы, сказывают Погыча, а до ней от Колымы парусным погодьем бежать сутки трои и больши.

11. А ныне на той Колыме реке от него всего осталось служилых Вторко Гаврилов.

Гидронимное значение выражается через сочетание имени собственного и существительного река (Колымарека, см. №№ 3, 6). При реализации двух других значений наблюдается вариативность Колыма-река / Колыма: Колыма-река - регионим в №№ 1, 2, 4, 11; Колыма - регионим в №№ 5, 9; Колыма - географический ориентир в №№ 7, 8, 10; Колыма-река - географический ориентир в №№ 5, 10. Вероятно, в используемых конструкциях при выражении значения 'географический ориентир' сема 'река' также не исключается.

Конечно, В деловой письменности XVII в. это не единственный пример одновременного употребления нескольких способов для выражения интересующих нас значений. Ср.: ... Да он же, Алешка, в роспросе сказал - Ковыма де река людна и в Ковыму де пали многие реки, а Ковыма де с Лену величиною. А Митька де Зырян воротился. И пошел де он, Митька, по Ковыме с иеловальником с Петрушкою Новоселовым по указу и по наказной памяти стольника и воеводы Петра Петровича Головина («Из ранних сообщений о р. Колыме и походе на эту реку Дмитрия Зыряна», не ранее 1642 г., № 29) [15]. Так, одновременное употребление интересующего нас имени собственного как в сочетании с лексемой «река» (чаще), так и без нее (с «наслоением» чередования фонетических вариантов Колыма/Ковыма) находим в «Отписке приказчика Колымского зимовья Тимофея Булдакова...» (1652 г., № 100): В прошлом во 157-м году послан я, Тимошка, из Якутикого острогу на государеву службу на Ковыму реку <...> ...служилые люди, которые служат государеву службу на Ковыме со 
мною <...> А на Колыме реке служебные всякие заводы покупают дорогою большею ченою. <...> всякие заводы на Колыме дороги. [15].

С одной стороны, модель изменения типа Колымарека $\rightarrow$ Колыма (словосочетание «Название реки + существительное река» с территориальным значением $\rightarrow$ «Название реки» с территориальным значением) имеет многочисленные аналогии за пределами Северо-Востока России (на Дону, на Волге и т.д.). С другой стороны, по мере освоения север-восточных земель, эта модель активно пополнялась новыми реализациями, например: Да я ж, холоп твой, был на Анандыре на новой реке и с Анандыря зимою перешел с товарыщы своими на лыжах с нартами за Нос, на Пенжину реку. А Пенжина, государь, река безлесная, а людей по ней живет много, род словут коряки. («Челобитная казачьего десятника Михаила Стадухина», 1659/60 г., № 37) [15]. А на Пенжине живут коряки пустобородые, лицом русоковаты, ростом средние, говорят своим особым языком... (««Скаска» казачьего пятидесятника В. Атласова о его походе на Камчатку в 1697 г.» $[16$, с. 108]).
Итак, изучение письменных источников, в частности деловой письменности XVII в., позволяет уточнить формирование семантики топонима «Колыма». Наряду с отмеченными в научной литературе значениям этого имени собственного («гидронимное», «ресурсное», «лагерное», «административное») сегодня функционирует и «узкое» территориальное значение - 'территория, прилегающая к реке Колыме'. Среди пространственных значений оно появилось первым, возникло оно очень рано, этот регионим известен с XVII в. На протяжении всех последующих столетий оно долгое время было основным, а в XX в. в связи с интенсивным изучением и значительным экономическим развитием Северо-Востока СССР было дополнено другими, более широкими значениями. Как показывает анализ деловых документов, «узкая» территориальная семантика первоначально появилась у словосочетания «Колыма-река», а затем развилась у интересующего нас гидронима. Региональный аспект в употреблении интересующих нас значений проявляется в том, что «узкое» значение более характерно для Якутии, а «широкое» - для Магаданской области (сегодня регионимы «Колыма» и «Магаданская область» функционируют как синонимы).

\section{ЛИТЕРАТУРА}

1. Аверинцев С.В. Экспедиция Рыбохозяйственной станции в низовья и дельту р. Лены летом 1930 года (с картой) / С.В. Аверинцев // Труды Якутской научной рыбохозяйственной станции. 1932. Выпуск 2. С. 7-56.

2. Аникин А.Е. Этимологический словарь русских диалектов Сибири: заимствования из уральских, алтайских и палеоазиатских языков / А.Е. Аникин. Москва : Новосибирск : Наука, 2000.768 с.

3. Богородский А.А. Медико-топографическое описание Гижигинского округа / А.А. Богородский // Журнал Министерства внутренних дел. 1853. № 10. 0тд. III. Ч. II. C. 49-138.

4. Войцеховский Б. Чукчи уверены, что прогневали предков. Как северные народы первыми ощутили на себе последствия глобального потепления / Б. Войцеховский // Lenta.ru. URL: https://lenta.ru/articles/2020/11/07/klimat (дата обращения: 15.11.2020).

5. Врангель Ф.П. Путешествие по северным берегам Сибири и по Ледовитому морю, совершенное в 1820, 1821, 1822, 1823 и 1824 г. экспедициею, состоявшею под начальством флота лейтенанта Фердинанда фон-Врангеля / Ф.П. Врангель. Санкт-Петербург : Тип. А. Бородина и К, 1841. Ч. 2. 360 с.

6. Гехтман И.Е. Золотая Колыма : Очерки / И.Е. Гехтман. Хабаровск : Дальгиз, 1937. 173 с.

7. Гоголева Е.М. Лексемы «материк» и «Колыма» в общенациональном словаре и в региональной традиции / Е.М. Гоголева // Колымский гуманитарный альманах. 2007. Выпуск 2. С. 199-208.

8. Горячев А. Черский поселок Колымы. Полный фотоотчет / А. Горячев. // LiveJournal. URL : https://goryachev.livejournal.com/49622.html (дата обращения: 15.11.2020).

9. Калашников А.А. Экспедиция Н.М. Березкина 06 изысканиях пути Среднеколымск - Гижига : [2015] // Страница о Якутске. URL : https://www. yakutskhistory.net/исторические-личности/коллежский-асессор-березкин-н-м/экспедиция-н-м-березкина-в-гижигу (дата 0бращения: 15.11.2020).

10. Копосов Л.Ф. Лингвистическое источниковедение: история и современное состояние / Л.Ф. Копосов // Вестник МГОУ. Серия : Русская филология. 2012. № 3. С. 20-24.

11. Котков С.И. Очерки по лексике южновеликорусской письменности XVI-XVIII веков / С.И. Котков. Москва : Наука, 1970. 315 с.

12. Леонтьев В.В. Топонимический словарь Северо-Востока СССР / В.В. Леонтьев, К.А. Новикова; науч. ред. Г.А. Меновщиков. Магадан : Книжное издательСтВ0, 1989. 456 C.

13. Литке Ф.П. Плавания вокруг света и по Северному Ледовитому океану / Ф.П. Литке. Москва : Дрофа, 2009. 1036 с.

14. Мокиенко В.М. Большой словарь русского жаргона / В.М. Мокиенко, Т. Г. Никитина. Санкт-Петербург : Норинт, 2001. 720 с.

15. Орлова Н.С. Открытия русских землепроходцев и полярных мореходов XVII века на северо-востоке Азии : Сборник документов / Н.С. Орлова. Москва : Географгиз, 1951. 620 c.URL: http://www.vostlit.info/Texts/Dokumenty/Reisen/XVII/1600-1620/0tk_russ_mor_sev_cost_azii (дата 06ращения: 15.11.2020).

16. Русская тихоокеанская эпопея / составление и введение В.А. Дивина ; Исторические очерки, комментарий и примечания В.А. Дивина и др. Хабаровск : Книжное издательство, 1979. 607 с.

17. Русские экспедиции по изучению северной части Тихого океана во второй половине XVIII в. : Сборник документов. Москва : Наука. Главная редакция 
восточной литературы, 1989.400 c.

18. Никова Т. Алексей Курило: Мне жаль Черский, который мы потеряли... / Т. Никова // SakhaNews. URL : https://www.1sn.ru/204163.html (дата обращения: 15.11.2020).

19. Шепилева 0.Е. Отражение фонетических особенностей диалектной речи старожилов Крайнего Северо-Востока России в историко-этнографических текстах / 0.Е. Шепилева // Научный диалог. 2019. № 3. С. 147-162. D0I: 10.24224/2227-1295-2019-3-147-162.

(с) Семенов Алексей Иванович (aisemenoff@mail.ru).

Журнал «Современная наука: актуальные проблемы теории и практики»

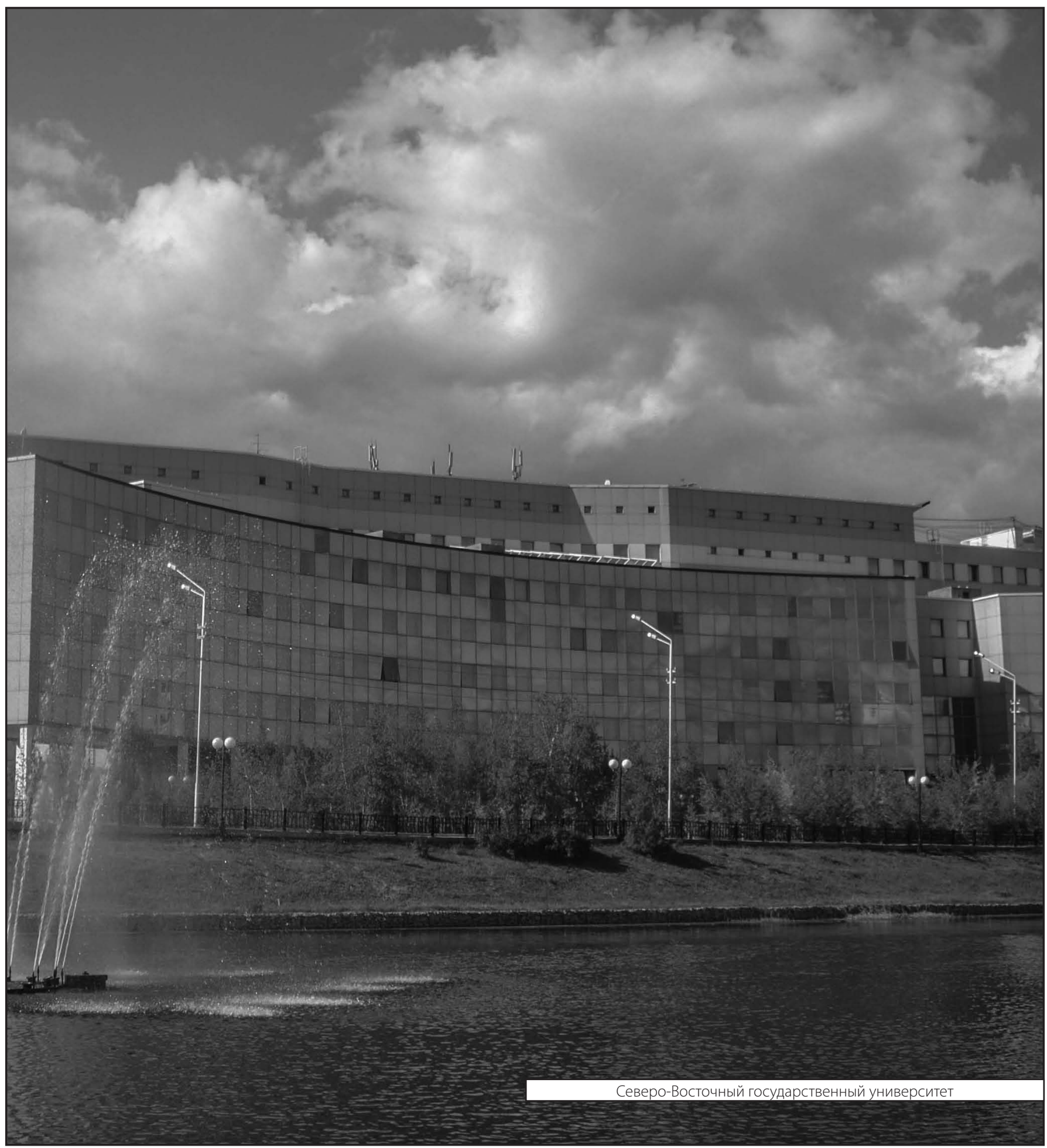

